\title{
Shift of English Literature Learning from Classroom to Online: Preferences and Attitude of Bangladeshi Undergraduate Students
}

\author{
Md. Zohorul Islam \\ Green University of Bangladesh, Dhaka, Bangladesh \\ zohorul@eng.green.edu.bd
}

\begin{abstract}
ARTICLE HISTORY
Received : 8 January 2021

Revised : 19 January 2021

Accepted : 30 January 2021
\end{abstract}

\section{KEYWORDS}

Online Class

Literature

Covid-19

Students'Preferences

Attitude

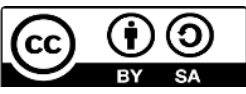

\begin{abstract}
This paper explores the English Literature classes that are taught online in Bangladeshi universities and the attitude of the students towards these classes. The new-normal after the Covid-19 outbreak forced the students to attend classes online and their experience about the English Literature classes are investigated in this research. The total number of participants for this study was ninety-seven. The research was conducted on the students of the Department of English in four private universities in Bangladesh. A survey questionnaire was prepared consisting of twenty questions to collect the data online. The data was analysed with quantitative method of research. Digital statistical software Microsoft Excel used for the data analysis. The research finding shows that the students find poetry and short story classes effective and engaging in online classes but showed unfavorable attitude towards novel and drama classes. The results also show that the students want more opportunity to share their opinion in the class and preferred visual aids in online classes. This study implies that while the instructors and the students are going through an unprecedented challenge of learning English Literature in online classrooms, the obstacles can be mitigated through increasing interactive classroom discussion and precise use of multimedia tools while teaching different genres of English Literature.
\end{abstract}

\section{Introduction}

Education at all levels faced the greatest challenge because of Covid-19 pandemic and institutions ceased faceto-face classes and relied on online classes using technology (Daniel, 2020; Aristovnik et al., 2020). The challenge of adapting the new methods of e-learning is relatively new to the larger portion of the teachers and students in Bangladesh (Sultana \& Khan, 2020). Institutions have given priority to the health issue but have tried to continue the learning through online teaching to keep the students engaged and motivated when social distancing became an irreplaceable norm (Ferdeus \& Shifat, 2020; Marinoni et al., 2020). The connection between the students and the teachers in a literature class is significant because, for the students, literary text "represents authentic feelings of their authors and this produces a strong motivation in the learners," (Babaee \& Yahya, 2014, p. 82).

The previous researches reflect that the success of the recent phenomenon of online class depends on the attitude and satisfaction of the students. A study by Sultana \& Khan (2020) shows that positive attitude of the students about the online class can create an effective teaching learning atmosphere where decisive factors of the students' satisfaction can be the e-learning platforms and instructor's teaching method. It is important to mention that the instructors are also facing difficulties adapting to the online teaching methods. A case study about online teaching learning in Bangladesh by Rony \& Awal (2019) shows that, although, the teachers are changing their perception of their negative views about online classes, their teaching is being troubled by many external factors too. Nonetheless, there are still several aspects of online classes that need to be addressed and students' feedback can be a crucial factor. English Literature or literature in general is a diverse field and different forms of literary texts have their own peculiarities where the learners need to approach the text differently (Savvidou, 2004).

A student from the Department of English gets to explore several genres of the English Literature (e.g., poetry, short story, novel, drama, literary criticism, etc.), which means the student's involvement in the lecture is a crucial factor in the teaching learning process (Van, 2009). In an online class, teaching this diverse field can get difficult for the instructor as certain genres require special setting and active involvement from the students in the lesson. For example, reading William Shakespeare's (15641616) Hamlet, Charles Dickens's (1812-1870) Great Expectation, reading the poem Stopping by Woods on a Snowy Evening by Robert Frost (1874-1963) or the essay of Study by Francis Bacon (1561-1626) require different approaches from the teacher as well as the learner. 
Although previous researches have been conducted on the complex nature of the teaching-learning process in the online classroom in general, the field of teaching English Literature online has not been explored. The unique discipline of English Literature needs to find out the best possible ways of conducting the teaching-learning process in an online classroom. Furthermore, students' attitude and their preferences in the English Literature classes is important to take adequate actions which can be used for an effective online classroom environment. Echoing the previous studies above, this study aims at exploring features that influence the attitude of the student about online English literature classes in Bangladesh and expectations of the students in literature classes from the instructors. The study intends to find out whether the students of English Literature in Bangladesh have a healthy attitude about the online classes that started after the Covid-19 pandemic. This study also aims at finding out the preferences of the students of their instructor's way of delivering lectures and classroom materials.

This study only focused on the students' attitude and opinion about the online English literature classes in selected private universities of Bangladesh. The entire research does not include the opinion of the instructors from the selected universities. Other important aspects that were not considered in this study are the external factors (e.g., internet connection, device) which can shape the attitude of the students toward online classes. Moreover, the study focused on the students' attitude and expectation from the classroom but the research did not include the students' attitude on online assessment methods.

The researcher moved forward with two central research questions to understand the attitude of the students about literature classes conducted online. The followings are the research questions of this study:

a. What is the attitude of the students in the process of online English literature classes in Bangladesh?

b. How do students react towards different approaches of the instructors in online English literature classes?

\section{Literature Review}

Recent studies have interpreted that the rapid spread of Covid-19 has forced institutions to conduct online classes shifting from the onsite/face-to-face classes (Mpungose, 2020). Covid-19 fetched massive changes in the world and the field of education had to acclimatise to the existing situation. After the World Health Organization (WHO) declared Covid-19 as a pandemic in March 2020 (Spinelli \& Pellino, 2020), initially, "this situation challenged the education system across the world and forced educators to shift to an online mode of teaching overnight. Many academic institutions that were earlier reluctant to change their traditional pedagogical approach had no option but to shift entirely to online teaching-learning," (Dhawan, 2020, p. 5).
Dhawan (2020) also predicts that the students face difficulty to fully absorb the meaning of a particular topic because most of the online classes are conducted based on one-way interaction (teacher to student). The study recommended that personal attention can be a way to establish an effective learning environment. Similar research conducted by Mondol and Mohiuddin (2020, p.242) found that there are several external factors that affects the teaching learning process in an online classroom, for example, "teaching learning process gets hampered resulting in the motivation swing and less participation,".

Reading (1989) argues that while teaching literature, partaking dialogues with the students in a classroom are indispensable because, "this is a subject whose disciplinary landscape and characteristic forms of inquiry have been formed in the classroom and in dialogue with students". In his book Reading Literature, Reading (1989) suggests that a literature syllabus includes a vast number of contents and learning happens when "students actually are in terms of knowledge, skills, and motivation....and must seek genuine response and engagement from other students, leading to new knowledge and understanding," (p. 35). Online classes have often been regarded by the student as passive where the 'spontaneous exchange' of ideas does not happen between the teacher and the students in real time (Shenoy et al., 2020). Bertea (2009) puts emphasis on the efficiency in communication between the teacher and students while conducting classes online. The author presents that the 'lack of human interaction' may cause the performance and attitude deficiency in the online classroom. A study by Bertea (2009) also shows that the students may feel 'socially isolated' because of the lack of human interaction in an online classroom.

Attitude often refers to an expression or preference of a person through which attributes of a certain aspect are judged (Ramdhani et al., 2012). According to Sumarwan (2004), attitude can be measured through cognitive (knowledge), affective (emotional) and conative (behavioral tendencies) components of a person (Ramdhani et al. 2012). Another research about measuring the attitude of the students in online classes by Bertea (2009) shows that the previous research has proved that 'attitude indicates a certain degree of possibility of adopting certain behavior'. Motivation and positive attitude can play an important role in the learning of the students. Ghazali et al. (2009) suggests that the students with a positive attitude in a literature class "will spend more effort to learn by using strategies such as asking questions, volunteering information and answering questions," (p. 51). Ghazali et al. (2009) research shows that the students "felt upset when they did not get enough opportunity to share their views during the literature lessons," (p. 54). It elaborates that the lecture in a class is not as significant as having sufficient time to discuss a topic because 'teacher's explanation and notes was ranked as the fifth most important strategy in teaching literature, followed by using audio visual in literature classes," (p. 55). 


\section{Method}

\subsection{Participants}

The data for this research was collected from the students who are in their $6^{\text {th }}$ or upper trimester of the Department of English of four private universities in Bangladesh. Three of the universities are located in Dhaka city and another one is located outside the city. It is important to mention that in private universities of Bangladesh, the curriculum is designed in a way where a student usually requires to complete four years (12 trimesters) of study to complete their graduation. The research participants were selected from the groups who had the chance to attend face-to-face literature classes as well as online literature classes. Students who got enrolled in the universities after the covid-19 pandemic or had the opportunity to attend the onsite literature classes for a short period of time before the social-distancing was imposed, were not considered for this study. Hence, the students attending university in their first and second year were not considered for the study. This study is based on convenience and purposeful sampling of the participants.

\subsection{Instrument}

This study follows the quantitative research approach to find out the student's attitude about the online literature classes. The data was collected online as the researcher followed the social-distancing while collecting the data. A survey questionnaire was prepared for the students and sent to the current students using e-mails and two social media, namely Facebook and Whatsapp. The survey questionnaire was designed following the similar research conducted by the other researchers, for instance, Shorna and Suchona (2020) and Lee (2008). It is important to mention that the survey questionnaire was significantly modified for the purpose of this study. The researcher used the five point Likert scale to set the range of the responses and quantify the data. The ranges were set from always to never and for some questions strongly agree to strongly disagree. The point values of the responses were always $=5$, usually $=4$, sometimes $=3$, occasionally $=2$, never $=1$; strongly agree $=5$, agree $=4$, neutral $=3$, disagree $=2$ and strongly disagree $=1$. The questionnaire required a closed-ended answer from the participants. The questionnaire was divided into three sections:

a. Section 1: Instruction

b. Section 2: Classroom Practices in Online English Literature Classes

1) Sub-section 1: Communication

2) Sub-section 2: Digital Contents (e.g., e-book, PDF files, PowerPoint/Google Slides)

3) Sub-section 3: Lecture Delivery

c. Section 3: Attitudes

1) Sub-section 1: Expectations

2) Sub-section 2: Effectiveness of Different Genres and Digital Contents

3) Sub-section 3: Preferences

Table 1. Student's Involvement in the English Literature Classes

\begin{tabular}{|c|c|c|c|c|c|c|}
\hline Statements & $\begin{array}{c}\text { Total } \\
\text { Responses }\end{array}$ & $\begin{array}{c}\text { Always } \\
(\%)\end{array}$ & $\begin{array}{c}\text { Often } \\
(\%)\end{array}$ & $\begin{array}{l}\text { Sometimes } \\
(\%)\end{array}$ & $\begin{array}{c}\text { Rarely } \\
(\%)\end{array}$ & $\begin{array}{l}\text { Never } \\
(\%)\end{array}$ \\
\hline $\begin{array}{l}\text { Instructors ask me questions in the online English } \\
\text { literature classes. }\end{array}$ & 96 & $14 \%$ & $59 \%$ & $19 \%$ & $6 \%$ & $2 \%$ \\
\hline $\begin{array}{l}\text { Instructors ask me to read aloud from the literary } \\
\text { texts in the online class }\end{array}$ & 97 & $24 \%$ & $64 \%$ & $5 \%$ & $7 \%$ & $0 \%$ \\
\hline $\begin{array}{l}\text { Instructors ask me to give my opinion about a topic } \\
\text { in our online Literature classes. }\end{array}$ & 97 & $27 \%$ & $58 \%$ & $11 \%$ & $4 \%$ & $0 \%$ \\
\hline $\begin{array}{l}\text { Instructors encourage me to unmute and share } \\
\text { opinions during a lecture. }\end{array}$ & 97 & $27 \%$ & $59 \%$ & $9 \%$ & $4 \%$ & $1 \%$ \\
\hline $\begin{array}{l}\text { Instructors check my understanding on a topic by } \\
\text { asking questions at the end of the lecture. }\end{array}$ & 96 & $27 \%$ & $48 \%$ & $15 \%$ & $7 \%$ & $3 \%$ \\
\hline
\end{tabular}

\section{Results}

The analysis of the collected data from the survey questionnaire is presented in the following tables and figures.

\subsection{Communication}

Table 1 shows that $14 \%$ of the participants agreed that the instructor asked questions during the class lecture. While responding about reading aloud texts in the classroom, $24 \%$ of the research participants say that the instructor always practices this norm in the classroom. However, the response about the questions regarding check for understanding at the end of the lecture, sharing opinion when the teacher invites the participants and instructor's motivation about unmuting and sharing opinion during a lecture, $27 \%$ students indicate these practices take place in the classroom. The analysis shows that most of the students do not have direct involvement in the classroom. The larger portion of the students fails to have effective dialogues with the instructor during a literature class. 


\subsection{Digital Class Materials}

Figure 1 is the response of the student to subsection 2 and $58 \%$ of the students appreciate the teacher when whole class discussion is conducted rather than discussing texts and digital study materials. The analysis also shows that $45 \%$ feels disappointed when they read digital e-books in the class through screen sharing, rather than reading from the printed text books. Figure 1 also illustrates that $48 \%$ students do not like lectures that involve lots of digital presentation tools such as PowerPoint/Google Slides. The analysis shows that the students are yet to be habitat with the digital contents of the online literature classes. The teacher's approach to conduct the whole class discussion is appreciated by the majority of the students.

Figure 1. Students' Attitude about Digital Contents in an Online Literature Class

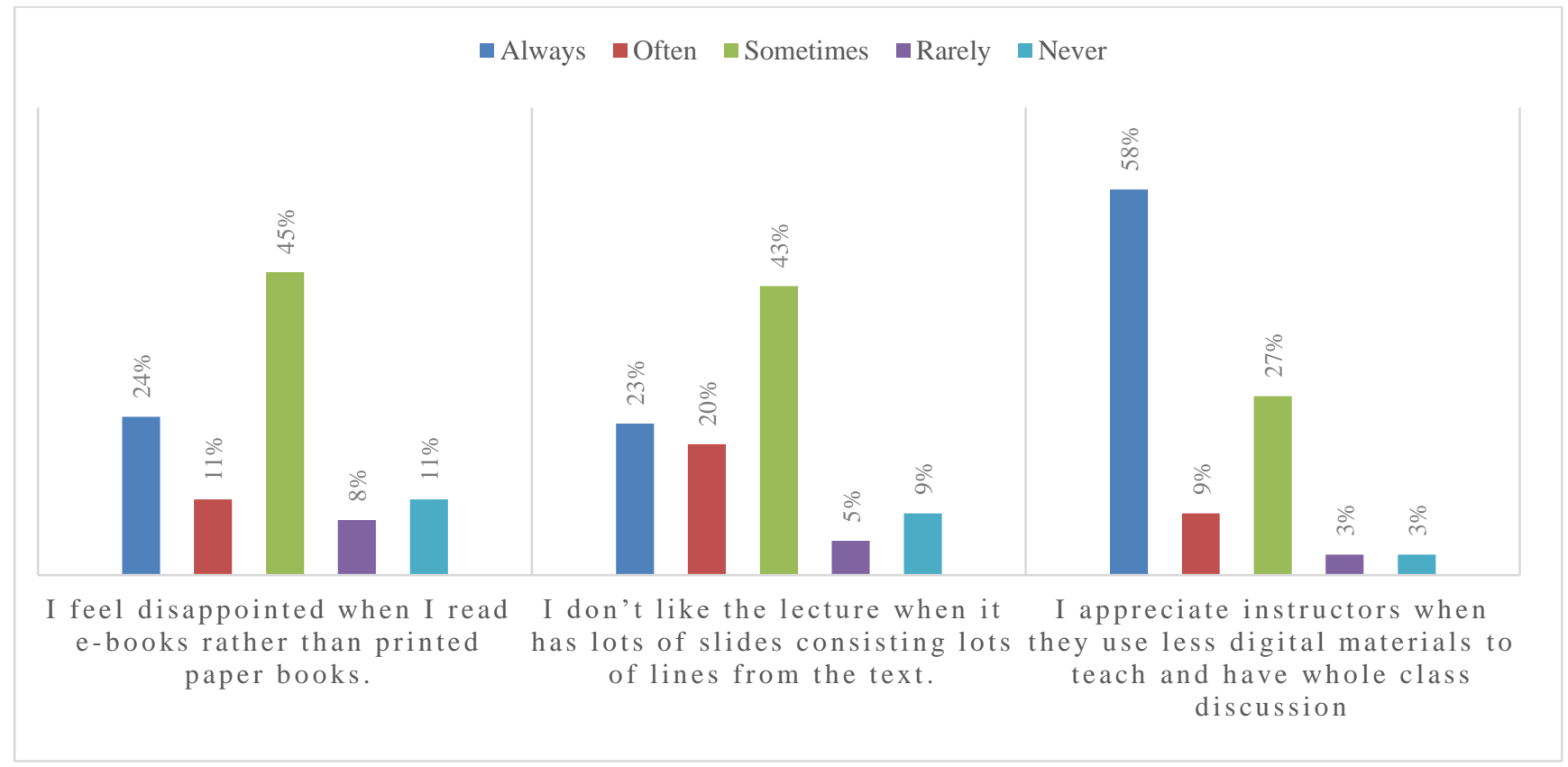

Table 2. Students' Perception about Lecture Delivery by the Instructor Using Technology.

\begin{tabular}{|c|c|c|c|c|c|}
\hline Statements & $\begin{array}{l}\text { Strongly } \\
\text { Agree }\end{array}$ & Agree & Neutral & Disagree & $\begin{array}{l}\text { Strongly } \\
\text { Disagree }\end{array}$ \\
\hline $\begin{array}{l}\text { I want the teacher to give me significant time to think and share } \\
\text { my thoughts. }\end{array}$ & $28 \%$ & $54 \%$ & $13 \%$ & $2 \%$ & $3 \%$ \\
\hline $\begin{array}{l}\text { I do not understand the instructors when they write comments } \\
\text { using the computer mouse. }\end{array}$ & $3 \%$ & $11 \%$ & $34 \%$ & $37 \%$ & $14 \%$ \\
\hline $\begin{array}{l}\text { I understand lines from a text when the instructor provides } \\
\text { explanation in footnotes of the slides. }\end{array}$ & $21 \%$ & $57 \%$ & $18 \%$ & $4 \%$ & $1 \%$ \\
\hline
\end{tabular}

\subsection{Lecture Delivery}

Table 2 shows the students preferences about the lecture delivery of an instructor in the class. The analysis shows that $54 \%$ of students want the instructor to invest more time on the students to let them think about a topic and then share their thoughts. While sharing their opinion about using a computer mouse to write comments on the pages $37 \%$ of the students are in favor of this technique used by teachers. The table also reveals that $57 \%$ students want footnotes in the slides to understand the explanation of the lines quoted from the text.

\subsection{Effectiveness of Different Genres and Digital Contents in Online Classes}

Table 3 shows the attitude of the students about the effectiveness of the different genres of English Literature and the digital contents shared by the teachers in online classes. The analysis shows that $39 \%$ students believe that the online classes are effective for poetry lectures and $45 \%$ students believe that the short story lectures are effective for online classes. The analysis shows a significant decline 
while opined on the effectiveness of the online classes of novels and drama classes. Table 3 shows that $33 \%$ of students find the lectures on English novels classes are effective online. However, only $27 \%$ of students opined that the drama classes are effective in the online classes. In addition, Table 3 shows that $47 \%$ students find the use of presentation slides helpful while learning English literature in online classes and $40 \%$ students think that the presentation slides make the lectures attractive.

Table 3. Students' Perception about Lecture Delivery by the Instructor Using Technology

\begin{tabular}{|c|c|c|c|c|c|}
\hline Statements & $\begin{array}{l}\text { Strongly } \\
\text { Agree }\end{array}$ & Agree & Neutral & Disagree & $\begin{array}{l}\text { Strongly } \\
\text { Disagree }\end{array}$ \\
\hline I find online classes effective for poetry lectures & $9 \%$ & $39 \%$ & $22 \%$ & $21 \%$ & $9 \%$ \\
\hline I find online classes effective for short story lectures & $15 \%$ & $45 \%$ & $22 \%$ & $11 \%$ & $6 \%$ \\
\hline I find online classes effective for novel lectures & $7 \%$ & $33 \%$ & $22 \%$ & $25 \%$ & $13 \%$ \\
\hline I find online classes effective for drama lectures & $7 \%$ & $27 \%$ & $27 \%$ & $25 \%$ & $14 \%$ \\
\hline $\begin{array}{l}\text { PowerPoint/Google Slides are helpful in literature } \\
\text { classes }\end{array}$ & $34 \%$ & $47 \%$ & $9 \%$ & $5 \%$ & $4 \%$ \\
\hline $\begin{array}{l}\text { I find the use of technology in literature classes } \\
\text { attractive. }\end{array}$ & $22 \%$ & $40 \%$ & $24 \%$ & $13 \%$ & $2 \%$ \\
\hline $\begin{array}{l}\text { I enjoy and feel comfortable in online English } \\
\text { Literature classes. }\end{array}$ & $13 \%$ & $24 \%$ & $33 \%$ & $16 \%$ & $13 \%$ \\
\hline
\end{tabular}

\subsection{Preferences}

The analysis of Table 4 shows that $35 \%$ students show disagreement in using visual aids (PDF, PPT, Google Slides, etc.) by the teacher in an online English literature class. On the other hand, $38 \%$ of the respondents opined that the teacher should bring the summary of the long text instead of larger volumes of books. Finally, while giving a verdict about their attitude towards English literature classes in the future, $29 \%$ students agreed that in the future online classes should always be conducted online.

Table 4. Students' Perception about Lecture Delivery by the Instructor Using Technology

\begin{tabular}{|c|c|c|c|c|c|}
\hline Statements & $\begin{array}{c}\text { Strongly } \\
\text { Agree }\end{array}$ & Agree & Neutral & Disagree & $\begin{array}{l}\text { Strongly } \\
\text { Disagree }\end{array}$ \\
\hline $\begin{array}{l}\text { Teachers should conduct lecture-based classes without visual } \\
\text { aids (e.g., PDF, PPT, Slides, etc.) }\end{array}$ & $6 \%$ & $22 \%$ & $13 \%$ & $35 \%$ & $24 \%$ \\
\hline $\begin{array}{l}\text { Teachers should bring a summary of a long text in online } \\
\text { classes. }\end{array}$ & $38 \%$ & $42 \%$ & $10 \%$ & $6 \%$ & $3 \%$ \\
\hline $\begin{array}{l}\text { Teachers should always conduct English literature classes } \\
\text { online in the future. }\end{array}$ & $10 \%$ & $22 \%$ & $29 \%$ & $21 \%$ & $19 \%$ \\
\hline
\end{tabular}

\section{Discussion}

The results of this study, which are displayed in the figures and tables above, shows that the students are still getting familiar with the online classes of English literature in selected Bangladeshi private universities. The finding reveals that the students prefer poetry and short stories which are short in nature to study in the online classes. On the other hand, novels and drama classes are still preferred in the face-to-face classes by the students. The students have given emphasis on the classroom discussion rather than the 'digital content based' lectures. The research also reveals that the majority of the students find the use of digital contents attractive, however, the students want the instructor to keep a significant portion of time for discussion in the classroom. The findings can help us to answer the research questions that were asked at the beginning of this research.

\subsection{Students Attitude towards learning English Literature in Online Classrooms}

The research reveals that the students in selected private universities in Bangladesh show little enthusiasm towards online classes of English literature. The students expect to have more discussion with the teacher about certain topics. Hence, the majority of the students want the instructor to allocate a significant amount of time to have discussion with their peers as well as the instructors. 
Therefore, to further assess the findings from the previous researches (Bertea, 2009; Mondol \& Mohiuddin. 2020; Aristovnik et al., 2020), this study reveals that English Literature classes need unique attention from the instructors regarding classroom discussion. When the students are contributing in the online classrooms and the teacher encourages them to participate in the discussion, the harmony of the enthusiastic literature classroom can be achieved even in the online classes (Dixson, 2010). It has been observed that some students tend to stay quiet in the online classroom, they are hoping to get encouragement from the instructors to share the views about the contents of the classroom.

The attitude of the students towards the use of technology and digital contents (e.g., e-books, PDF Materials) are neutral and majority of them have a negative attitude towards the novel or drama classes that are being conducted online. This study also shows that the students find poetry and short story classes effective on online platforms. Hence, the instructors need to find out ways means to engage the students in an online classroom and conduct classes of novels and drama to bring back the effectiveness of the contents. The effectiveness of an online English Literature class will largely depend on how enthusiastically the students are sharing their knowledge, just like the students used to do in the onsite classroom.

\subsection{Students' Preferences in Online English Literature Classes}

The study reveals that the students in the selected private universities in Bangladesh do not enjoy lectures that contain a lot of slides and majority of them think that the electronic books-based classes make them often disappointed. The results also demonstrate that they want the instructor's use of digital contents extensively should not be followed in the English literature classes. Previous researches show that the online classes during the Covid-19 pandemic of using a lot of multimedia tools in the classroom (Mpungose 2020; Marinoni et al., 2020). This study shows that the peculiarity of the literature classes demands less use of multimedia tools such as PowerPoint Slides in an online literature class. Majority of the students disagreed with the notion that the teacher should prepare PowerPoint slides or other digital contents for English literature classes. Students has shown interest in having more online discussions in online English literature classes.

Considering the findings of this study, this paper suggests instructors bring digital content responsibly and address the needs of the students in their lesson plans to accommodate the feedbacks of the students. However, when the instructors are teaching short genres such as poetry or short stories, using the digital contents are encouraged. This study notes a significant aspect of online classes regarding English Literature that the students of the $21^{\text {st }}$ century are still focusing on the human interaction in the classroom to discuss and share ideas with the teachers and their peers to make it a meaningful experience.

\section{Conclusion}

The effect of Covid-19 has pushed the Bangladeshi Universities to continue their programs in online platforms. This research was conducted to find out the perception and attitude of the students towards effectiveness of new classroom practices of English literature classes by the instructors from the department of English in selected private universities of Bangladesh. The results of the research shows that the students are eager to get back to the physical classrooms to learn English literature. The study also reveals that the students want the instructors to focus on the discussion rather than the use of different digital features that are being commonly used by the other disciplines.

To recapitulate the first research questions of this study, the attitude of the students of Bangladeshi undergraduate students about online English Literature classroom is changing from negative to positive. The possibilities of continuing English Literature classes online have enormous potentiality given that the students are getting enough opportunity to contribute in the classroom. On the other hand, regarding the second research question, the use of digital contents and instructor's approaches have been viewed positively for shorter genres of English Literature but approaches about the longer genres of English Literature needs new focuses to be more effective.

Hence, a strategy needs to be developed by the policy makers to find a way to engage the students in more online discussions. One important aspect that should be noted is the limited amount of time the instructors and students got to get familiarised with the situation created by Covid-19 is a defining factor in shaping the attitude of the students in online classes. Moreover, this research was designed in a way that did not consider the external factor that might shape the attitude of the students about online English literature classes. Further research can be done to find out the solutions of this study's limitations and investigate external factors that can shape the attitude of the students regarding online English literature classes.

\section{References}

Aristovnik, A., Keržič, D., Ravšelj, D., Tomaževič, N., \& Umek, L. (2020). Impacts of the COVID-19 pandemic on life of higher education students: A global perspective. Sustainability, 12(20), 1-34 https://doi.org/10.3390/su12208438

Babaee, R., \& Yahya, W. R. B. W. (2014). Significance of literature in foreign language teaching. International Education Studies, 7(4), 80-85.

Bacon, F. (1908). The Essays of Francis Bacon. C. Scribner's sons.

Bertea, P. (2009). Measuring students'attitude towards elearning. A case study. In Conference proceedings of » eLearning and Software for Education «(eLSE) (No. 
01, pp. 417-424). " Carol I" National Defence University Publishing House.

Daniel, S. J. (2020). Education and the COVID-19 pandemic. Prospects, 49(1), 91-96. https://doi.org/10.1007/s11125-020-09464-3

Dhawan, S. (2020). Online learning: A panacea in the time of COVID-19 crisis. Journal of Educational Technology Systems, 49(1), 5-22. https://doi.org/10.1177\%2F0047239520934018

Dickens, C. (1861). Great expectations (Vol. 1). JB Peterson \& Bros.

Dixson, M. D. (2010). Creating effective student engagement in online courses: What do students find engaging?. Journal of the Scholarship of Teaching and Learning, 10(2), 1-13

Ferdous, A. U., \& Shifat, N. F. (2020). Dealing with Mental Health in Online Learning: A Retrospect on ELT Teachers and EFL Learners during COVID-19 Pandemic. REiLA : Journal of Research and Innovation in Language, 2(3), 101-107. https://doi.org/10.31849/reila.v2i3.5217

Frost, R. (1998). Stopping by Woods on a snowy evening. literature: An introduction to fiction, Poetry, Drama, and Writing, 5, 775-76.

Ghazali, S. N., Setia, R., Muthusamy, C., \& Jusoff, K. (2009). ESL students' attitude towards texts and teaching methods used in literature classes. English language teaching, 2(4), 51-56.

Lee, I. (2008). Student reactions to teacher feedback in two Hong Kong secondary classrooms. Journal of second language writing, 17(3), 144-164.

Marinoni, G., Van't Land, H., \& Jensen, T. (2020). The impact of Covid-19 on higher education around the world. IAU global survey report. https://www.unibasq.eus/wpcontent/uploads/2020/06/iau_covid19_and_he_survey _report_final_may_2020.pdf

Mondol, M. S., \& Mohiuddin, M. G. (2020). Confronting Covid-19 with a Paradigm Shift in Teaching and Learning: A Study on Online Classes. International Journal of Social, Political and Economic Research, 7(2), 231-247. https://doi.org/10.46291/IJOSPERvol7iss2pp231-247

Mpungose, C. B. (2020). Emergent transition from face-toface to online learning in a South African University in the context of the Coronavirus pandemic. Humanities and Social Sciences Communications, 7(1), 1-9. https://doi.org/10.1057/s41599-020-00603-x
Ramdhani, A., Alamanda, D. T., \& Sudrajat, H. (2012). Analysis of consumer attitude using Fishbein multiattributes approach. International journal of basic and applied science, 1(1), 33-39.

Reading, A. (1989). Teaching literature. Longman. Londres.

Rony, H. A. Z., \& Awal, S. T. (2019). University teachers' training on online teaching-learning using online platform during COVID-19: A case study. Bangladesh Education Journal, 18(2), 57-64.

Savvidou, C. (2004). An integrated approach to teaching literature in the EFL classroom. The Internet TESL Journal, 10(12), 1-6.

Shakespeare, W. (1905). Hamlet. EP Dutton.

Shenoy, V., Mahendra, S., \& Vijay, N. (2020). COVID 19 lockdown technology adaption, teaching, learning, students' engagement and faculty experience. Mukt Shabd Journal, 9(4), 698-702.

Shorna, S. A, \& Suchona I. J. (2020). Bangladeshi undergraduates' attitude towards teachers' feedback on midterm scripts. Crossings: A Journal of English Studies. 11(1), 261-271

Spinelli, A., \& Pellino, G. (2020). COVID-19 pandemic: perspectives on an unfolding crisis. Journal of British $\begin{array}{lll}\text { Surgery, } & \text { 707(7), }\end{array}$ https://doi.org/10.1002/bjs.11627

Sultana, T., \& Khan, R. H. (2019). Investigating university students $^{\text {ee }}$ satisfaction on online class: Bangladesh perspective. Bangladesh Educational Journal, 18(2), 23-32.

Van, T. T. M. (2009). The relevance of literary analysis to teaching literature in the EFL Classroom. English Teaching Forum English Teaching Forum, 47(3), 2-9 